\title{
An insight on pediatric peripheral Lymphadenopathy: Atwo year cytological study in a tertiary care hospital
}

\author{
Shilpa G' ${ }^{1}$ CSBR Prasad ${ }^{2}$ \\ ${ }^{1}$ Dr Shilpa G, Assistant Professor, Department of Pathology, ${ }^{2}$ Dr CSBR Prasad, Professor, Department of Pathology, \\ Sri Devraj Urs Medical College, Banglore Tirupathi Highway, Tamaka, Kolar, Karnataka, India.
}

Address for Correspondence: Dr Shilpa G, 28, Chandhavi, 12 ${ }^{\text {th }}$ Main, $1^{\text {st }}$ Stage, BTM Layout, Bangalore, Email ID-gshilp@gmail.com

\begin{abstract}
Introduction \& Objective: Lymphadenopathy in pediatric population is an ever challenging situation. This study was done to study the cytological features of non-neoplastic and neoplastic lesions of enlarged lymph nodes by fine needle aspiration cytology (FNAC) and determine the pattern of diseases affecting the children below 18 years. Materials and Methods: 453 cases between the age group of 0-18 years, referred to the cytology section of the department of Pathology were included in the study over a period of two years. Special stains and biopsy were done in selected cases. Results: Majority of the cases were benign (97.60\%), while only $2.4 \%$ (13/543 cases) of cases were malignant. Reactive hyperplasia, tuberculous lymphadenitis, suppurative lymphadenitis, metastatic carcinoma and lymphoma were seen in $53.2 \%, 30.20 \%, 10.68 \%, 0.2 \%$ and $1.8 \%$ respectively. Cervical group of lymph nodes were the most frequently affected nodes. In 37 cases, the cytological diagnosis was compared with histopathological diagnosis. Conclusion: The most frequent cause for lymphadenopathy in pediatric population is reactive hyperplasia followed by tuberculosis. FNAC alone can be useful in establishing diagnosis in large number of cases in proper clinical setting and obviates the need for invasive procedures like surgery.
\end{abstract}

Key words: Cytology, Lymphadenopathy, Pediatric.

\section{Introduction}

Lymphadenopathy is one of the most common presenting complaints in pediatric age group with varied differential diagnosis [1]. Fine needle aspiration cytology (FNAC) of enlarged lymph nodes is a wellestablished first line diagnostic test in adult population [2]. In the pediatric population, however, the use of FNAC has met with some resistance and it is not well documented in the literature, with most literature describing only cervical group of lymphnodes [3-8]. In children with lymphadenopathy, clinical evaluation and radiological studies are done to assess the patient. The gold standard to diagnose malignancy is surgical biopsy, which has its own drawbacks and limitations. The value of FNAC, besides making a diagnosis, also lies in early direction of appropriate investigations. The knowledge of the pattern of lymphadenopathy in a

Manuscript received: $22^{\text {th }}$ April 2016

Reviewed: $4^{\text {th }}$ May 2016

Author Corrected; $15^{\text {th }}$ May 2016

Accepted for Publication: $28^{\text {th }}$ May 2016 given geographical region and age group is essential for making a confident diagnosis. The present descriptive study was undertaken to study the cytological patterns of non-neoplastic and neoplastic lesions of enlarged lymph nodes presenting in the pediatric population.

\section{Materials and Methods}

543 consecutive children in the age group of 0 to 18 years presenting with enlarged peripheral lymph nodes, referred to the Cytology Section of Pathology Department, over a period of 2 years were selected. Patients referred from both outpatient and inpatient departments were included. Patients with deep seated nodes and in whom FNAC was contraindicated were excluded from the study. In each instance, a brief clinical history, physical examination along with evaluation of relevant investigations, if available, was carried out. The FNAC procedure was performed using a $23 / 24 \mathrm{G}$ needle attached to $10 \mathrm{ml}$ syringe after taking an informed consent. Multiple sites were aspirated. The 
aspirated material was smeared onto 4 slides in each case. Two slides were immediately immersed in $95 \%$ ethanol and remaining air dried. The air dried smears were routinely stained by Geimsa stain and alcohol fixed smears stained by Hematoxylin and Eosin stain $(\mathrm{H}$ and E) and Papanicolaou (PAP) stain. Special stains like Ziehl-Neelsonstain (ZN) stain for acid fast bacilli (AFB) were done whenever required. In 37 cases histopathologicalcorrelation was available. The data was analyzed by using Epi Info Version 7 (CDC, Atlanta, Georgia, USA).

\section{Results}

A total of 543 patients with lymphadenopathy were included in the study. In $97.60 \%(530 / 543$ cases) of the cases a benign diagnosis was offered, while only $2.4 \%$ (13/543 cases) of cases were malignant. Reactive hyperplasia, tuberculous lymphadenitis, suppurative lymphadenitis, metastatic carcinoma and lymphoma were seen in 53.2\%, $30.20 \%, 10.68 \%, 0.2 \%$ and $1.8 \%$ respectively (Table-1) (Figure-1). A solitary case of BCG lymphadenitis in a 9 month old child was also reported. In 18 cases (3.31\%), FNAC was inconclusive due to unsatisfactory smears. Cervical group of lymph nodes were involved most often in all types of lymphadenopathy, particularly Hodgkin's disease, which showed $100 \%$ involvement of cervical group of lymph nodes (Table-2). Among the tubercular lymphadenitis total AFB positivity was seen in $23 \%$ of cases (125/543 cases). Two cases of tubercular lymphadenitis presenting with generalized lymphadenopathy were retroviral positive. Cytological evidence of metastasis was present in $0.55 \%$ of cases, of which 2 cases were from seminoma while another case was diagnosed to be metastasis from germ cell tumor. 10 cases of Lymphoma were diagnosed in the study, which included 2 cases of Hodgkin's disease and 8 cases of Non-Hodgkin's Lymphoma (Figure-2). In 37 cases (3.31\%) the material obtained was inadequate for opinion. The initial cytological diagnosis was compared with the gold standard histopathological diagnosis in 37 cases. Thecomparison between FNAC findings andhistopathological findings along with sensitivity and specificity for each category is shown in Table 3.

Table 1: Distribution of various lesions of pediatric lymphadenopathy on fine needle aspiration cytology.

\begin{tabular}{|c|c|c|c|}
\hline SI. No. & Cytological Diagnosis & No. of Cases & Percentage \\
\hline 1. & Reactive lymphadenopathy & 289 & 53.22 \\
\hline 2. & Tubercular lymphadenitis & 164 & 30.2 \\
\hline 3. & Suppurative lymphadenitis & 58 & 10.68 \\
\hline 4. & BCG lymphadenitis & 1 & 0.2 \\
\hline 5. & Metastatic carcinoma & 2 & 0.55 \\
\hline 4. & Hodgkin's Lymphoma & 8 & 0.34 \\
\hline 5. & Non-Hodgkin's Lymphoma & 18 & 3.31 \\
\hline 6. & Unsatisfactory Aspirates & $\mathbf{5 4 3}$ & \\
\hline & Total &
\end{tabular}

Table 2: Lymph node groups involved in various types of lymphadenopathy (Excluding unsatisfactory smears.

\begin{tabular}{|c|c|c|c|c|c|c|}
\hline \multirow[b]{2}{*}{ Site } & \multirow{2}{*}{$\begin{array}{c}\text { Reactive } \\
\text { Lymphade } \\
\text { nitis }\end{array}$} & \multirow{2}{*}{$\begin{array}{c}\text { Tubercular } \\
\text { Lymphadeniti } \\
\text { s }\end{array}$} & \multirow{2}{*}{$\begin{array}{l}\text { Suppurative } \\
\text { Lymphadenit } \\
\text { is }\end{array}$} & \multirow{2}{*}{$\begin{array}{l}\text { Metastatic } \\
\text { carcinoma }\end{array}$} & \multicolumn{2}{|c|}{ Lymphoma } \\
\hline & & & & & Hodgkin's & Non-Hodgkin's \\
\hline Cervical & $\begin{array}{c}188 \\
(65.05 \%) \\
\end{array}$ & $\begin{array}{c}142 \\
(26.15 \%) \\
\end{array}$ & $38(65.51 \%)$ & $1(33.3 \%)$ & $\begin{array}{c}2 \\
(100 \%) \\
\end{array}$ & $\begin{array}{c}2 \\
(25 \%) \\
\end{array}$ \\
\hline Axillary & $\begin{array}{c}35 \\
(12.11 \%) \\
\end{array}$ & $\begin{array}{c}13 \\
(7.92 \%)\end{array}$ & $12(20.69 \%)$ & 0 & - & - \\
\hline Inguinal & $\begin{array}{c}34 \\
(\%) \\
\end{array}$ & $\begin{array}{c}10 \\
(6.1 \%) \\
\end{array}$ & $8(13.79 \%)$ & $2(66.67)$ & - & - \\
\hline Generalized & $\begin{array}{c}44 \\
(11.76 \%) \\
\end{array}$ & $\begin{array}{c}6 \\
(3.66 \%) \\
\end{array}$ & 0 & 0 & - & $\begin{array}{c}6 \\
(75 \%) \\
\end{array}$ \\
\hline Total & 289 & 164 & 58 & 3 & 2 & 8 \\
\hline
\end{tabular}


Table 3: Comparison of cytological diagnosis with histopathological study.

\begin{tabular}{|c|c|c|c|c|c|c|c|}
\hline \multirow{2}{*}{$\begin{array}{l}\text { SI. } \\
\text { No. }\end{array}$} & \multirow{2}{*}{$\begin{array}{c}\text { Cytological } \\
\text { diagnosis }\end{array}$} & \multicolumn{4}{|c|}{ Histopathological diagnosis } & \multirow{2}{*}{$\begin{array}{c}\text { Sensitivity } \\
(\%)\end{array}$} & \multirow{2}{*}{$\begin{array}{c}\text { Specificity } \\
(\%)\end{array}$} \\
\hline & & $\begin{array}{c}\text { Tubercular } \\
\text { lymphadenitis }\end{array}$ & $\begin{array}{c}\text { Reactive } \\
\text { lymphaden } \\
\text { opathy }\end{array}$ & $\begin{array}{l}\text { Metastatic } \\
\text { carcinoma }\end{array}$ & $\begin{array}{c}\text { Non- } \\
\text { Hodgkin's } \\
\text { Lymphoma }\end{array}$ & & \\
\hline 1 & $\begin{array}{c}\text { Tubercular } \\
\text { lymphadenitis }\end{array}$ & 16 & 0 & 0 & 0 & 94.1 & 100 \\
\hline 2 & $\begin{array}{c}\text { Reactive } \\
\text { lymphadenopathy }\end{array}$ & 1 & 12 & 0 & 1 & 92.3 & 95.8 \\
\hline 3 & $\begin{array}{l}\text { Metastatic } \\
\text { carcinoma }\end{array}$ & 0 & 0 & 3 & 0 & 100 & 100 \\
\hline 4 & $\begin{array}{l}\text { Non-Hodgkin's } \\
\text { Lymphoma }\end{array}$ & 0 & 1 & 0 & 3 & 75 & 97 \\
\hline
\end{tabular}

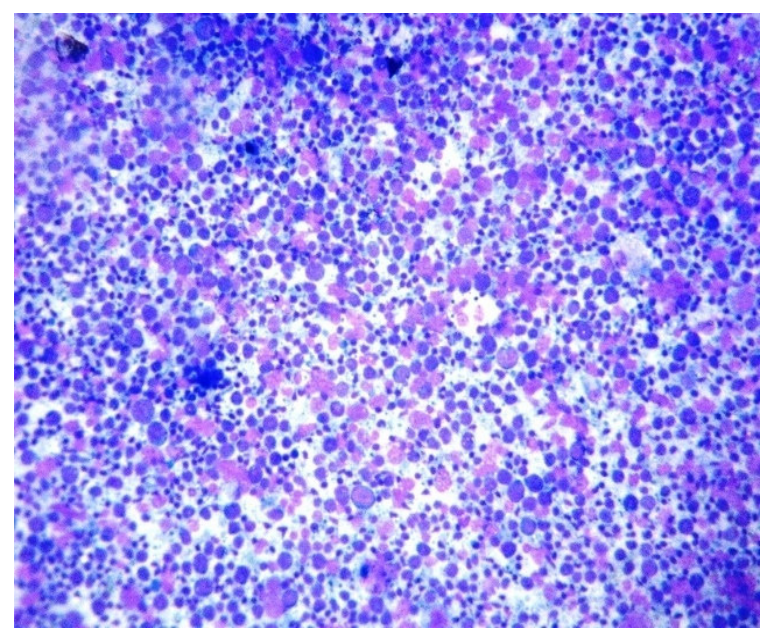

Figure-1: Photomicrograph of Reactive Lymphadenopathy showing polymorphous population of lymphocytes (Geimsa stain x 200)

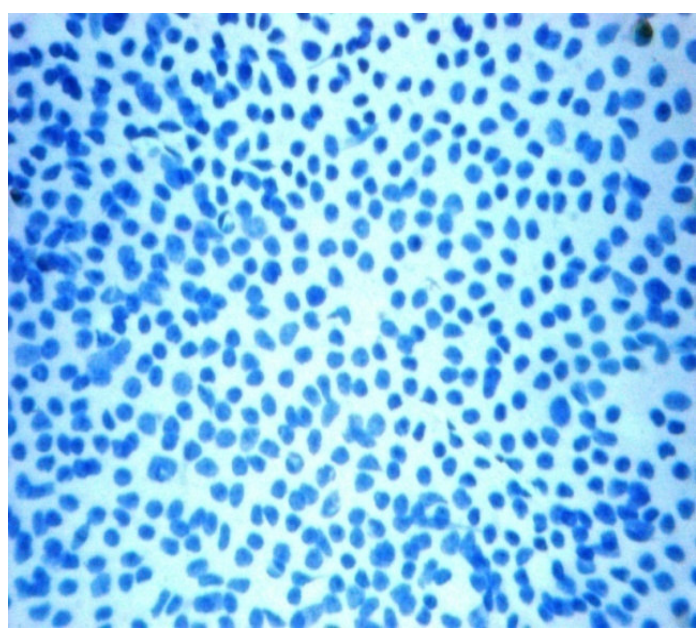

Figure-2- Photomicrograph of Non-Hodgkin's Lymphoma with monomorphic population of lymphocytes (Papanicolaou stain $\mathbf{x 4 0 0 )}$

\section{Discussion}

In this study we have presented our experience with 543 cases of pediatric lymphadenopathy over two years. The pattern of the lesions, with benign diagnoses being $97.60 \%$ and malignant cases of $2.4 \%$, is similar to the incidence reported in other studies [4, 7, 9-10]. In childhood the peripheral lymph nodes usually enlarge due to local inflammatory process [11]. Accordingly in our study Reactive lymphadenopathy (53.22\%) proved to be the overall common diagnosis. This was in conformance with findings in other studies [7,12-13]. The second most common diagnosis was tubercular lymphadenitis $(30.2 \%)$. In India lymphadenopathy is the common presentation of extra pulmonary tuberculosis with massive economical implication on the health care system. It is also resurging due to the increasing incidence of Human Immunodeficiency

Virus [14]. ZN stain used for identification of AFB when incorporated increases the diagnostic accuracy of FNAC [15]. In our study the AFB positivity was similar to findings of other studies in the literature from India $[7,12]$. Wright et alhave commented that the presence of AFB along with montoux test can lead to early diagnosis and prompt management of patients [16]. The definitive diagnosis of tuberculosis is made by culture, amplification of bacterial DNA by polymerase chain reaction. However the cost, time required and frequent negative results are some of the important limitations. FNAC of tubercular lymph nodes obviates the need for a biopsy which is also expressed by Lau SK et al [17].

FNAC is an important diagnostic tool to rule out malignancy. In pediatric population the incidence of 
neoplastic lesions of the lymph nodes is small. Nevertheless lymphadenopathy can be the first presenting symptom of an underlying disease; hence the possibility has to be ruled out. The technique of FNAC is extensively used for the diagnosis of lymphoma in pediatric age group. In our study Non-Hodgkin's lymphoma was the commonest with 2 cases of Hodgkin's disease also diagnosed. FNAC is also useful for staging and identifying residual disease or recurrences [18]. Three cases of metastatic diseases to lymph nodes were also seen in our study. However no comparison with other studies could be drawn due to small number of cases in our study.

Cervical lymph nodes were the most common group to be involved in this study. Tariq et al and Steel BL et al also found similar findings in their study $[19,20]$. Easy accessibility could be most plausible explanation to this finding. In 37 cases $(3.31 \%)$ the smears obtained were unsatisfactory for providing any opinion, with similar incidence being reported in study done by Annam et al [12]. However it has to be noted that FNAC not only offers tissue diagnosis, but also provides material for culture, immunocytochemistry, immunophenotyping, molecular diagnosis and electron microscopy in suspected cases [18].

In the present series there were 17 cases of tubercular lymphadenitis diagnosed by histopathology. 16 cases were correctly diagnosed by FNAC. In the remaining one case, epithelioid cells or giant cells could not be identified and they were misdiagnosed as reactive hyperplasia. Out of 14 cases of reactive lymphadenopathy; one case was subsequently diagnosed as granulomatous lymphadenitis without caseation on histopathological diagnosis, while one case turned out to be Non-Hodgkin's lymphoma. Histopathological examination was available for 4 cases of NHL diagnosed on cytology. 3 cases correlated with histopathology, while one case turned out to be reactive lymphadenopathy. This was because of the difficulty encountered in some cases to differentiate reactive hyperplasia from lymphoma of lymphocytic variety. The possibility of overlap among reactive hyperplasia and lymphocytic lymphoma is also mentioned in other studies [18]. The ever expanding histopathologic subclassification of NHL makes it clear that FNAC cannot be a substitute for histopathology. But FNAC can be an important first line diagnostic approach and be extremely useful during follow-up [21]. In a study done by Steel et althe authors suggested that immunophenotyping adds to the value of the biopsy procedure, but FNAC may help in deciding the site of biopsy and may be substituted for histology in the occasional patient in whom the surgical risks outweigh the diagnostic inaccuracy of the procedure [20]. The success rate of diagnosis of metastatic carcinoma was $100 \%$ in this study. The presence of clusters of atypical large alien cells indicated the diagnosis at a glance. Van De et al have also opined that FNACis an accurate diagnostic procedure to differentiate between benign and malignant peripheral lymphadenopathy in children and can avoid open biopsy in at least $60 \%$ of cases [8].

\section{Conclusion}

Lymphadenopathy in pediatric population is always a diagnostic challenge. In a resource limited facility it can be an important diagnostic tool available for initial assessment and to plan the further course of management. It is a minimally invasive, safe procedure which also helps to procure material for ancillary techniques to aid in definitive diagnosis. Along with a reassurance of benignity, confirmation of malignancycan be achieved and treatment initiated since the results are comparable to histopathological diagnosis.

\section{Funding: Nil, Conflict of interest: Nil Permission from IRB: Yes}

\section{References}

1. Park YW. Evaluation of neck masses in children. Am Fam Physician. 1995 Jun;51(8):1904-12.

2. Saboorian, M H, Ashfaq R. The use of fine needle aspiration biopsy in the evaluation of lymphadenopathy. SeminDiagnPathol. 2001 May;18(2):110-23.

3. Ingolfsdottir M, Balle V, Hahn CH. Evaluation of cervical lymphadenopathy in children: advantages and drawbacks of diagnostic methods.Dan Med J. 2013 Aug;60(8):A4667.

4. Gwili NM, Hadi MA, Eldin AN, Hassab HM, Eldin YS, Fadel SH, Mashali NA. Lymphadenopathy in a series of Egyptian pediatric patients and the role of pathology in the diagnostic workup.Pediatr Dev Pathol. 2014 Sep-Oct;17(5):344-59. doi:10.2350/14-03-1480OA.1.

5. Wakely PE Jr. Merits of fine-needle aspiration biopsy in children; Head and neck. Diagn Cytopathol. 1992;8(3):299-301. 
6. Ponder TB, Smith D, RamzyI. Lymphadenopathy in children and adolescents: role of fine-needle aspiration in management. Cancer Detect Prev.2000;24(3):228-33.

7. Khan RA, Wahab S, Chana RS, Naseem S, Siddique S. Children with significant cervical lymphadenopathy: Clinicopathological analysis and role of fine-needle aspiration in Indian setup. J Pediatr (Rio J). 2008 SepOct;84(5):449-54.doi:10.2223/JPED.1840.

8. van de Schoot L, Aronson DC, Behrendt H, Bras J. The role of fine-needle aspiration cytology in children with persistent or suspicious lymphadenopathy.J Pediatr Surg. 2001 Jan;36(1):7-11.

9. Jain M, Majumdar DD, Agarwal K, Bais AS, Choudhury M.FNAC as a diagnostic tool in pediatric head and neck lesions.IndianPediatr. 1999 Sep; 36(9):921-3.

10. Dey P, Mallik MK, Gupta SK, Vasishta RK. Role of fine needle aspiration cytology in the diagnosis of soft tissue tumours and tumour-like lesions. Cytopathology. 2004 Feb;15(1):32-7.

11. Leung AK, Robson WL. Childhood cervical lymphadenopathy.J Pediatr Health Care. 2004 JanFeb;18(1):3-7.

12. Annam V, Kulkarni MH, Puranik RB. Clinicopathologic profile of significant cervical lymphadenopathy in children aged 1-12 years. Acta Cytol. 2009 Mar-Apr;53(2):174-8.

13. el Hag IA, Chiedozi LC, al Reyees FA, Kollur SM. Fine needle aspiration cytology of head and neck masses. Seven years' experience in a secondary care hospital.ActaCytol. 2003 May-Jun;47(3):387-92.

14. Sarma PK, Chowhan AK, Agrawal V, Agarwal V. Fine needle aspiration cytology in HIV-related lymphadenopathy: experience at a single centre in north India. Cytopathology. 2010 Aug;21(4):234-9. doi: 10. 1111/j.1365-2303.2009.00712.x. Epub 2009 Oct 15.

15. Bezabih M, Mariam DW, Selassie SG. Fine needle aspiration cytology of suspected tuberculous lymphadenitis. Cytopathology. 2002 Oct;13(5):284-90.

16. Wright CA, Warren RM, Marais BJ. Fine needle aspiration biopsy: an undervalued diagnostic modality in paediatric mycobacterial disease. Int J Tuberc Lung Dis. 2009 Dec;13(12):1467-75.

17. Lau SK,WeiWI,Kwan S, Yew WW.Combined use of fine-needle aspiration cytologic examination and tuberculin skin test in the diagnosis of cervical tuberculous lymphadenitis. A prospective study.Arch Otolaryngol Head Neck Surg. 1991 Jan;117(1):87-90.

18. IyerVK.Pediatric lymphoma diagnosis: role of FNAC, biopsy, immunohistochemistry and molecular diagnostics. Indian J Pediatr. 2013 Sep;80(9):756-63. doi: 10.1007/s12098-013-1128-2. Epub 2013 Aug 8.

19. Ahmad T, Naeem M, Ahmad S, Samad A, Nasir A.Fine needle aspiration cytology (FNAC) and neck swellings in the surgical outpatient. J Ayub Med Coll Abbottabad. 2008 Jul-Sep;20(3):30-2.

20. Steel BL, Schwartz MR, Ramzy I. Fine needle aspiration biopsy in the diagnosis of lymphadenopathy in 1,103 patients. Role, limitations and analysis of diagnostic pitfalls. Acta Cytol. 1995 Jan-Feb;39(1):76-81.

21. Lee DH, Baek HJ, Kook H, Yoon TM, Lee JK, Lim SC. Clinical value of fine needle aspiration cytology in pediatric cervical lymphadenopathy patients under 12years-of-age. Int J Pediatr Otorhinolaryngol. 2014 Jan; 78(1):79-81. doi: 10.1016/j.ijporl.2013.10.054. Epub 2013 Nov 14.

\section{How to cite this article?}

Shilpa G, CSBR Prasad. An insight on pediatric peripheral Lymphadenopathy: Atwo year cytological study in a tertiary care hospital.Int J Pediatr Res.2016;3(6):385-389.doi:10.17511/ijpr.2016.i06.03. 